\title{
Szívinfarktusos betegek akut és rehabilitációs ellátása Györ-Moson-Sopron és Vas megyében
}

\author{
Simon Éva', Bakai Juditt² Dézsi Csaba András ${ }^{3}$, Nagy Lajos ${ }^{4}$, Tóth László ${ }^{5}$
}

\author{
${ }^{1}$ Korona Prevent-Med, Sopron \\ ${ }^{2}$ Soproni Gyógyközpont, Sopron \\ ${ }^{3}$ Petz Aladár Megyei Oktatókórház, Győr \\ ${ }^{4}$ Markusovszky Kórház, Szombathely
}

Levelezési cím: Dr. Simon Éva PhD, e-mail: sopron.esimon@gmail.com

\begin{abstract}
A Nemzeti Szívinfarktus Regiszter (NSZR) eredményesen müködik Magyarországon. Ennek alapján tudjuk, hogy jelentős mértékben csökkent a szívinfarktus halálozása az akut szakban. A 30 napos halálozási adatok azonban nemzetközi összehasonlításban kedvezőtlenek. A betegeknek ebben az időszakban rehabilitációs programokban van a legbiztonságosabb helyük. Az intézeti rehabilitáció hatékonyságának objektív tanulmányozása érdekében 2014. január óta az NRSZ-hez kapcsolódóan müködik a Nemzeti Szívinfarktus Regiszter Fekvőbeteg Rehabilitációs Adatbázis (NSZRFRA). Országosan a szívinfarktust túlélő és rehabilitációban részt vevő betegek mintegy $9 \%$-áról van információnk. A Petz Aladár Megyei Oktató Kórház Györ Kardiológiai Osztálya, a Markusovszky Kórház Szombathely Kardiológiai és Belgyógyászati Osztálya szoros szakmai együttmüködést folytat a Soproni Gyógyközpont Kardiológiai Rehabilitációs Osztályaival a rehabilitációra alkalmas és azt vállaló betegek javára.

A vizsgálat célja és módszere: 2014. január 1-től kezdődően 2016. december 31-ig három év adatainak elemzése, az országos adatok összehasonlítása a Győr-Moson-Sopron megyei és Vas megyei adatokkal.

Eredmények: Az országos átlaghoz képest lényegesen többen vesznek részt rehabilitációs programban, ebben a két megyében. Számos szövődményre - malignus ritmuszavar, szívelégtelenség, új keletủ angina pectoris -, valamint társbetegségekre - 2-es típusú diabetes mellitus, perifériás érbetegség, krónikus obstruktív tüdőbetegség, veseelégtelenség - a korai rehabilitáció során derül fény.

Következtetések: A betegség természetéről kapott információk segítik a betegek terápiahüségét, csökken az ismételt akut kórházi ellátásuk gyakorisága, a 30 napos és az egyéves halálozás. A multiprofesszionális intézeti - a későbbiekben ambuláns - rehabilitációs program egységes szakmai irányelvek alapján minden arra alkalmas beteg számára indokolt. Javul a beteg életminősége, ezzel összefüggésben csökkennek az egészségügyi kiadások.
\end{abstract}

Kulcsszavak: szívinfarktus kezelése, kardiológiai rehabilitáció, regiszter, szekunder prevenció, életminőség

Heart attack treatment of acute and rehabilitation phase in Györ-Moson-Sopron and Vas County

The National Registry of Myocardial Infarction (NSZR) is working effectively in Hungary. The death caused by heart attack in acute stage shows significantly downward tendency. The result are unfavourable when comparing data in a 30-days term with international data. In these times are rehabilitation programs the safest for the patients. Studying the effectiveness of the institutional rehabilitation quite objective, the National Registry of Myocardial Infarction In-Patient Rehabilitation Database (NSZR-FRA) is working since January 2014. Nationwide we have information about $9 \%$ of the in-patients who survived a heart attack and took part in rehabilitation. The Cardiological Department of the Petz Aladár Hospital Györ, and the Cardiological and Internal Department of the Markusovszky Hospital Szombathely have close professional cooperation with the Cardiac Rehabilitation Departments of Elisabeth Hospital Sopron in favour of patients who are capable and willing to take part in rehabilitation.

The target and the method: From the 1th of January 2014 until the $31^{\text {th }}$ of December 2016 monitoring the data of the three year, and comparing the national data with the data from Győr-Moson-Sopron County and Vas County.

Results: Comparing to the national average, significantly more patients took part in rehabilitation program in these two counties. Several complications - arrhythmia, heart failure and new angina pectoris - and co-illnesses diabetes are explored during rehabilitation.

Conclusion: The information of the nature of sicknesses is helping the patient's devotion to the therapy, the frequency of rehospitalisation is lower, the death rate decreased. The multiprofessional institutional - later ambulant - rehabilitation program with standard professional guidelines is reasonable for every capable patient. The life-quality of patients will increase and connecting to that, the expenses of health care will decrease.

Keywords: heart attack treatment, cardiac rehabilitation, register, secunder prevention, quality of life 


\section{Bevezetés}

A szívinfarktusban meghalt betegek aránya Magyarországon fokozatosan csökken. A KSH adatai alapján, amíg 1993-ban 15000 beteg, 2003-ban 11000 beteg, addig 2014-ben 5872 beteg halt meg ebben a betegségben. A halálozási statisztika és a születéskor várható élettartam adatainak elemzése alapján Józan (1) epidemiológiai korszakváltásról beszél, aminek lényege a kardiovaszkuláris halálozás mintegy 35\%-os csökkenése. Ennek egyik oka a heveny szívinfarktus halálozásának csökkenése.

A Nemzeti Szívinfarktus Regiszter (NSZR) a magyar egészségügyi adatbázisok egyik meghatározó tényezőjeként müködik a hazai szívinfarktus-ellátás jellemzésére. 2010. január 1-től indult, mint önkéntes részvételen alapuló program. Fokozatos fejlődése során 2014. január 1-től már kötelező az adatszolgáltatás (2).

Prof. dr. Jánosi András és munkatársai közleménye a Nemzeti Szívinfarktus Regiszter adatai alapján rámutatott, hogy a szívinfarktusos betegek kórházi halálozása az utóbbi időszakban jelentős mértékben javult (3). Ebben a tanulmányukban az ST Elevációs Miokardiális Infarktus (STEMI) és a Non ST Elevációs Miokardiális Infarktus (NSTEMI) kórházi, a 30 napos, valamint az egyéves halálozást elemezték. A STEMI és NSTEMI diagnózissal kezelt betegek halálozása kapcsán megállapították, hogy a perkután koronária-intervenció mindkét típusú infarktusban nagyon jelentősen javította a betegek rövid- és hosszú távú életkilátásait. Ugyanakkor az egyéves halálozás 77\%-a az akut panaszt követő 30 napon belül következett be. A 30 napon belül meghalt betegek 72,8\%-ánál, az egy éven belül meghalt betegek $56 \%$-ánál a halál a prehospitális időszakban történt.

A három hónapos és egyéves halálozást a szekunder prevencióban jelentőséggel bíró, komplex rizikófelmérést követő kezelés alkalmazása kedvezően befolyásolja. Ezeknek a betegeknek a nemzetközi és hazai ajánlások alapján egyértelmúen ún. korai rehabilitációs programokban kell(ene) részt venniük, ami segítené életminőségük javulását és az egészségügyi kiadások csökkenését $(4,5)$.

Nemzetközi adatok is azt igazolják, hogy az evidenciákon alapuló kezelés arányának növekedése mindkét infarktustípus esetén mind a 30 napos, mind az egyéves halálozás csökkenését eredményezte (6). A jelentősnek talált prehospitális halálozás aránya a lakosság felvilágosításával is csökkenthető, amelyben a rehabilitációs programoknak szintén nagy szerepe van $(7,8)$, hiszen az infarktusok jelentős aránya már ismert koszorúsér-betegekben következik be.

\section{Szívinfarktus Regiszter Fekvöbeteg Rehabilitációs Adatbázis NSZR-FRA}

A magyarországi statisztikai adatok elemzése adta a Nemzeti Szívinfarktus Regiszter Fekvőbeteg Rehabili- tációs Adatbázissal (NSZR-FRA) való kiegészítésének gondolatát. Célunk a STEMI-t és NSTEMI-t szenvedett és túlélt, rehabilitációra alkalmas betegek kardiológiai rehabilitációban való részvétele valós adatainak megismerése.

A megvalósítás feladatát a Magyar Kardiológus Társaság Prevenciós és Rehabilitációs Munkacsoportja kezdeményezte és a javaslat megvalósítása a Nemzeti Szívinfarktus Regiszterhez kapcsolódott. Tekintettel arra, hogy jelenleg a járóbeteg-rehabilitáció szervezett formában még nem múködik Magyarországon, egyelőre csak a fekvőbeteg-adatokra támaszkodhatunk. Hasonlóan az NSZR 2010-es indulásához, a fekvőbeteg-rehabilitációban részt vevő betegek adatainak gyűjtése jelenleg kizárólag a rehabilitációs osztályok/ részlegek szakmai felelősségén, önkéntes adatszolgáltatásán alapul.

Az NSZR adataiból tudjuk, hogy 2014-ben 12 061, míg 2015-ben 12536 beteget regisztráltak. A rögzítési fegyelem itt is jelentős mértékben eltér az egyes intézetek között. Jánosi és munkatársai (2) 2015. évről öszszegyűjtött adataiból kiderül, hogy a betegek közel fele $(44,45 \%)$ otthonába távozott, közülük 26,4\% másik kórházi osztályra került. Az akut osztályokon az átlagos ápolási idő 5,2 nap volt. A fekvőbeteg-rehabilitációs kezelés lehetőségét a betegek 49\%-ának ajánlották fel, de ezt a betegek kevesebb, mint $8 \%$-a vette igénybe. A kórházi időszak alatt a betegek 6,6\%-a meghalt. Azt nem tudjuk pontosan, hány beteg vett részt rehabilitációs kezelésben.

2014. január 1. és 2016. december 31. között a NSZR Fekvőbeteg Rehabilitációs Adatbázisban összegyűjtött adatokat elemeztük. Abban az időszakban 2073 fö adatainak elemzésére volt módunk. A 29 felkért osztály/részleg közül 16-an vettek részt ebben az időszakban a rehabilitációs adatszolgáltatásban. A Fekvőbeteg Rehabilitációs Adatbázisban az akut miokardiális infarktust szenvedett betegek csupán 9\%-a szerepel.

A rehabilitáció kapcsán felállított új diagnózisok jelentőségét mutatja a 1. ábra. Az adatbázisban szereplő 2073 beteg közül 170 beteg esetében derült fény korábban nem diagnosztizált 2-es típusú cukorbetegségre, 147 betegnél pedig az elvégzett boka-kar index alapján perifériás érbetegségre. Ennél is nagyobb figyelmet

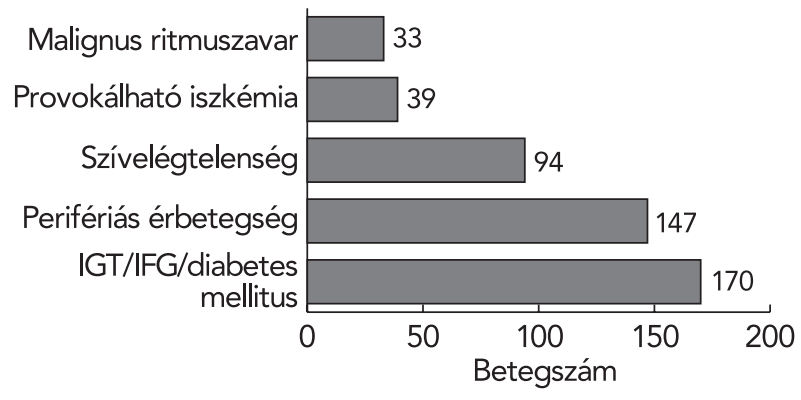

1. ÁBRA. Rehabilitáció során diagnosztizált új társbetegségek 


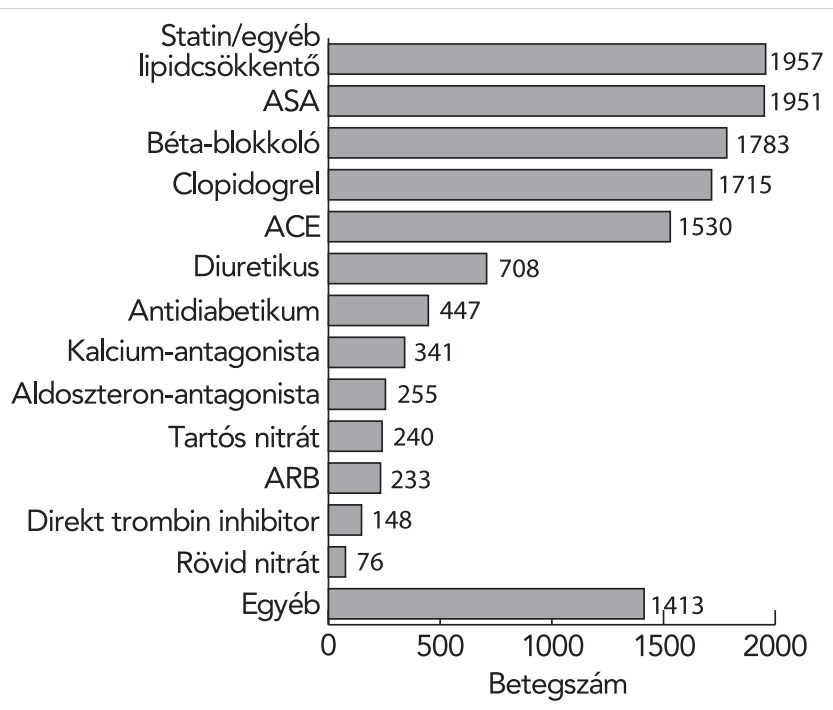

2. ÁBRA. A rehabilitációból távozáskor javasolt gyógyszerek gyakorisága

érdemlő és a korai halálozást jelentősen befolyásoló adat, hogy 94 betegnél az akut szakban nem ismert szívelégtelenség került felismerésre, ezek a betegek így máris megkaphatták a komplex egyénre szabott terápiát. Annál a 69 betegnél pedig, akinél malignus ritmuszavar, illetve provokálható iszkémia derült ki, további aktív kardiológiai kezelés vált szükségessé, az ismételt katéteres beavatkozások, illetve ICD-kezelés történt náluk. Több esetben rehabilitációról kerültek betegek transzplantációs listára.

Általános tapasztalat szerint az akut infarktust ellátó intézetben a nagy forgalom miatt nincs idő a megkezdett terápia optimalizálásának kivárására, a kívánt nyugalmi szívfrekvencia és a tünetmentesség elérésére.

Az adatbázisban szerepel a betegek gyógyszeres terápiája. A jelenlegi fejlesztés eredményeképpen lehetőség van az akut szak terápiájának áttekintésére, „átemelésére”, ezért már nem szükséges minden gyógyszert újként rögzíteni. A 2. ábra alapján megállapítható, hogy a betegek nagyon jó arányban megkapják az „evidence based medicine” elvei alapján a szükséges gyógyszereket. A betegek rehabilitáció során szerzett ismeretei adják a reményt, hogy a betegek együtt-

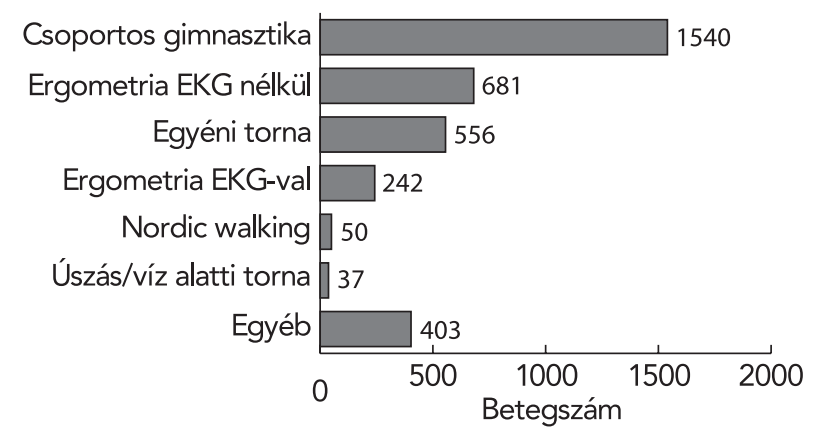

3. ÁBRA. Tréningen való részvétel módja müködése, adherenciája hosszú távon is eredményre vezet.

\section{Motiváció az eredményes szekunder prevencióhoz}

A rehabilitációs programon kapott információ és motiváció függvénye, hogy a betegek az őket ért sokkoló hatás után a későbbiekben hogyan lesznek képesek visszatérni a korábbi életük színterére. Az életminőségük megtartásához vagy javításához szükséges aktivitást a későbbiekben csak akkor képesek megőrizni, ha a rehabilitációs team ebben segíteni tudja őket. Ismert adat, hogy a szorongó, depressziós, vagy arra hajló beteg más egyéb kedvezőtlen hatások mellet nem meri vállalni a fizikai aktivitás rendszeres végzését sem (9). A 3. ábra jelzi azokat a változatos mozgásformákat, amelyeket az egyes centrumok lehetőségeiktől függően alkalmaznak. Csoportos vagy egyéni mozgáskezelésben minden rehabilitációban részt vevő beteg részesül. A fokozottan veszélyeztetett betegeknek rendelkezésére áll a minimumfeltételek között szereplő monitoros tréning, amelynek alkalmazása szívelégtelenségben szenvedő és/vagy malignus ritmuszavarra hajlamos betegeknél nélkülözhetetlen. Bizonyított, hogy a hirtelen halál esélye megfelelő tréning körülmények között nem nagyobb, mint a tünetmentes magas rizikójú személyek között.

\section{A rehabilitáció elérhető́ minden alkalmas beteg számára}

Az Országos Egészségbiztosítási Pénztár adataiból egyértelműen kiderül, hogy Magyarországon jelenleg van elegendő fekvőbeteg kardiológiai rehabilitációs ágy, amely többek között a STEMI-t, NSTEMI-t évente elszenvedett és túlélt mintegy 1500 betegnek is

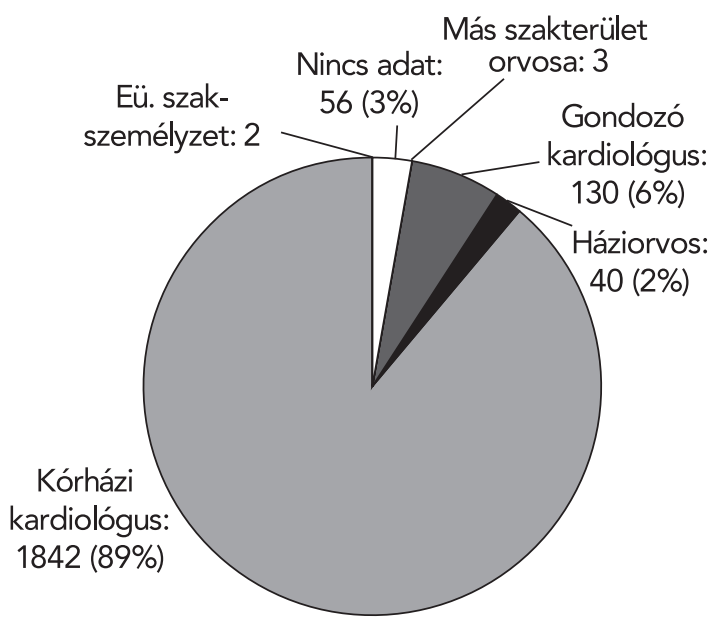

4. ÁBRA. A betegek döntését befolyásoló személyek 
rendelkezésére áll. 2015-ben átlagosan 1743 ágy állt rendelkezésre. 2016-ban további fejlesztések eredményeképpen még több ágy, összesen 1831 ágy állt rendelkezésre az ország különböző részein, ahol évente 26000 beteg átlagosan 20 napos rehabilitációs ellátására van lehetőség. Az NSZR adataiból láttuk, hogy jelenleg az arra alkalmas betegek csupán 49\%-a kapott rehabilitációs programra ajánlatot és közülük mindössze $7,7 \%$ vette ezt igénybe. Kérdés, mi magyarázza ezt a meghökkentően alacsony számot. A 4. ábra erre magyarázat lehet. Ebből kiderül, hogy a betegek elsöprő többsége, a vizsgálati csoportban 89\%-uk, a kórházi kardiológusára hallgat. Csupán 6\%-uk figyel a gondozó kardiológusra és a maradék néhány százalékra hat az egészségügyi szakszemélyzet, illetve más szakterület orvosa. Nagy a felesősége tehát a kórházi kardiológusnak, többek között az intervenciós kardiológusnak a beteg döntésének segítésében (4. ábra).

\section{NSZR-FRA figyelmet érdemlö eredményei}

A vizsgált időszakban, az akut regiszterben szereplő betegek mindegy 9\%-áról vannak adataink. A rehabilitációban részt vevő 2073 betegnél 483 új diagnózis került felismerésre és kezelésre, ugyanazon betegek körében 160 betegnél pozitív terheléses teszt történt és a rehabilitációról közülük 67 beteget további intézeti szakellátásra irányítottak. Nagyon fontos információ, hogy meghatározó mértékben a kórházi akut kardiológus befolyásolja a beteg döntéseit, így nemcsak a beutaló kiállításában, hanem a rehabilitációban való részvétel elfogadásával kapcsolatban is kiemelkedő a szerepük.

\section{Limitáció}

Az adatok elemzését számos tényező korlátozza. Ezek közül a legfontosabb az alacsony betegszám, illetve az a tényező, hogy nem tudjuk igazolni, hogy a rehabilitációra kerülő betegcsoport jellemzői alapvetően megegyeznek-e a rehabilitációra nem kerülő többséggel. Nem tudjuk, hogy a magasabb iskolai végzettségú, tanulás iránt nyitottabb, vagy az átlagosnál betegebb, rosszabb funkcionális osztályba sorolható betegek kerültek rehabilitációs programba. Így a mért eredmények általános kiterjeszthetősége is korlátozott.

\section{Az akut és rehabilitációs együttmúködés jó példája Györ-Moson-Sopron- és Vas megyében}

Területi ellátási kötelezettség alapján a Soproni Gyógyközpont kardiológiai rehabilitációs osztályai látják el a győri Petz Aladár Megyei Oktatókórház és a szom-

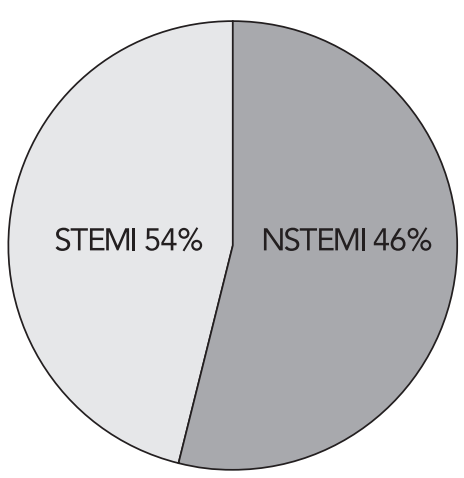

5. ÁBRA. Győrben kezelt 1453 beteg STEMI, NSTEMI megoszlása

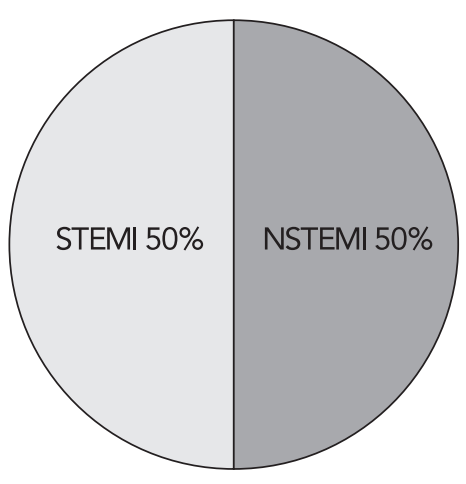

6. ÁBRA. Szombathelyen kezelt 1007 beteg STEMI, NSTEMI megoszlása

bathelyi Markusovszky Kórház hemodinamikai központjában és kardiológiai osztályain STEMI és NSTEMI diagnózisokkal kezelt betegeit. Az évtizedek óta folyamatosan fejlődő és kölcsönös előnyökön alapuló szoros szakmai együttmüködés eredménye, hogy a Győr-Moson-Sopron megyei és Vas megyei rehabilitációra alkalmas és azt vállaló betegek az országos átlagnál lényegesen magasabb arányban részesülhetnek, ún. korai kardiológiai rehabilitációban.

A vizsgált időszakban, 2014. január 1. és 2016. december 31. között összesen 1453 beteget kezeltek Győr-

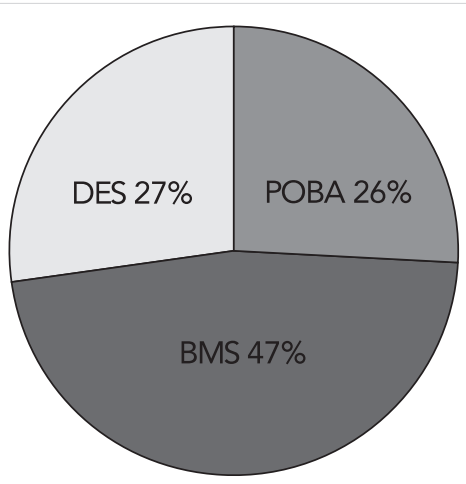

7. ÁBRA. Győrben végzett katéteres beavatkozások 


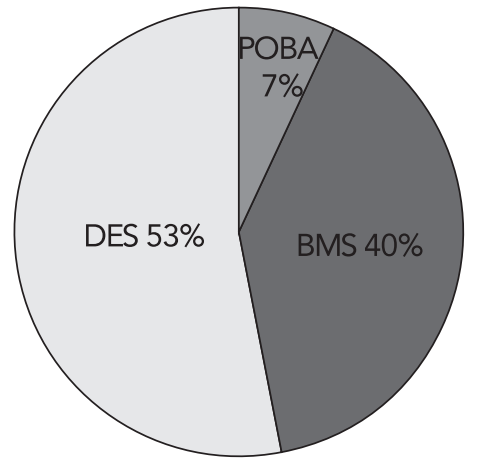

8. ÁBRA. Szombathelyen végzett katéteres beavatkozások

ben, míg 1007 beteget Szombathelyen STEMi, illetve NSTEMI diagnózisokkal. Az 5. ábra mutatja a két diagnózis megoszlását Győrben, a 6. ábra ugyanezt Szombathelyen.

A győri hemodinamikai laboratóriumban elvégzett beavatkozások típusát mutatja a 7. ábra. A percutan koronária-intervenciók 47\%-ban bare-metal stent (BMS), 27\%-ban gyógyszerkibocsátó stent (DES) és 26\%-ban hagyományos ballon-angioplasztika (POBA) volt a vizsgált 1457 szívinfarktusos betegnél.

A szombathelyi hemodinamikai laboratóriumban végzett beavatkozásokat a 8. ábra mutatja. Az 1007 vizsgált szívinfarktusos beteg 53\%-a DES-t, 40\%-a BMS-t és 7\%-a POBA-t kapott.

\section{Győri Petz Aladár Megyei Oktatókórház adatai}

Győri Petz Aladár Megyei Oktatókórházban kezelt 1453 betegekről az osztály saját informatikai rendszeréből kapott adatok állnak rendelkezésre 2014. január 1-2016. december 31-ig.

Ezek szerint a hazabocsátott betegek száma 1207 fő, más intézménybe áthelyezett betegek száma 64 fö, belső áthelyezés (intézményen belül) 71 fő volt. 103 beteg hunyt el.

Rehabilitációs javaslatot kapott 1323 fő, fizikai vagy szellemi okok miatt alkalmatlannak véleményeztek 27 főt. A javaslatot elutasító betegek száma 90 fő.

Rehabilitációra küldött betegek száma 1233 fö, ebből áthelyezéssel Sopronba került 27 fő. Az osztályról való távozás és a rehabilitáció között eltelt napok száma 7-28 nap.

A szombathelyi Markusovszky Kórház adatai A szombathelyi Markusovszky Kórházban kezelt 1007 beteg adatai 2014. január 1-2016. december 31-ig a Nemzeti Szívinfarktus Regiszterből származnak.

Ebből nem derül ki egyértelműen a betegek további sorsa. Annyi tudható, hogy a hazabocsátott betegek száma 292 fő, más osztályra áthelyezett betegek száma 186 fő. Szívsebészetre távozott 13 fő és elhunyt 34 fö.
Rehabilitációs javaslatot kapott 756 fő, fizikai vagy szellemi okok miatt nem javasolták 211 fő rehabilitációs kezelését. Az osztályról való távozás és a rehabilitáció között eltelt napok száma átlagosan 5,45 nap.

A nemzetközi irodalmi adatok szerint akut eseményt követően a betegek 50\%-a kap tájékoztatást rehabilitációról, azok 50\%-a fogadja el a lehetőséget és azok $50-70 \%$-a fejezi be a programot (11).

Győr, Szombathely és Sopron szoros és rugalmas szakmai együttmüködése eredményeképpen ezen a földrajzi területen élő betegek jelentősen nagyobb mértékben részesülhetnek kardiológiai rehabilitációs ellátásban.

Győrben az arra alkalmasnak vélt betegek 91\%-a, Szombathelyen a betegek $75 \%$-a kapott tájékoztatást, javaslatot intézeti rehabilitációs programban való részvételre.

A Soproni Gyógyközpont adatai szerint Győrből nem érkezett meg a betegek 10,6\%-a. Szombathelyről a betegek 9,9\% nem jelent meg a rehabilitációs kezelésen. Győr-Moson-Sopron megyéből a javaslattal ellátott betegek $89,4 \%$-a, Vas megyéből a javaslattal ellátott betegek 91,1\%-a megkezdte a rehabilitációt.

\section{NSZR-Fekvőbeteg Rehabilitációs Adatbázis első három évének tapasztalatai}

A kezdeti nehézségek mellett figyelemre méltó, hogy az adatszolgáltatás kizárólag a rehabilitációt végzők szakmai érdeklődését tükrözi, nem kötelező jellegű és nem kapnak finanszírozást a feladat elvégzésére. A személyzet- és időhiány a megvalósítás legnagyobb hátráltatója. Szükség lenne az akut és rehabilitációs adatbázis összekapcsolásának további fejlesztésére is, amelyre törekvések vannak.

\section{Fő feladatok az akut ellátás oldaláról}

Az eredményesség érdekében legfontosabb feladat, hogy a kórházi elbocsátás előtt megfelelő információt kapjanak a betegek a rehabilitáció szükségességéről és elérhetőségéről, valamint a megadott tájékoztatás a minőségbiztosítás részeként a beteg dokumentációjában követhető legyen. Más országok gyakorlata szerint ezt a feladatot célzott módon kiképzett szakszemélyzet is elvégezheti, valamint a rehabilitációs beutaló kitöltésével, elküldésével, a hely biztosításával legyen csak befejezett a beteg akut ellátása.

\section{Fő feladatok a rehabilitációs ellátás oldaláról}

A területi hozzáférhetőség javult, ugyanakkor a rehabilitációs osztályok/részlegek fogadókészségének, rugalmasságának javítása fontos feladat. A beteg együtt- 
müködésének biztosítása, a motiválás, az adherencia fenntartása nélkül nem lehet eredményes a rehabilitációs tevékenység. A fekvőbeteg-ellátásban rendelkezésre áló szakmai team, a felhalmozott ismeret és tapasztalat a most alakuló járóbeteg-ellátás szervezésében, működtetésében felhasználható. Új és ígéretes lehetőség az e-health, multimedia, telemedicina, telemonitorozás fejlesztése, az otthoni rehabilitáció elterjesztése és a betegklubok, közösségek támogatása, közösségi oldalakra megfelelő információs anyagok biztosítása. A beteg életminőségének javulása a munkaképes korú személyek reintegrálása a társadalomba a munkavállaló és a munkaadó közös érdeke. A társadalom idősödése miatt a nyugdíjas korosztály önellátása, aktivitásának fenntartása létfontosságú érdek.

\section{Következtetések}

Már az 1990-es évek óta egyértelmüen bizonyítást nyert, hogy a korai kardiológiai rehabilitáció költséghatékony, csökkenti a mortalitást és a betegek számára további minőségi életéveket eredményez (10). A szakmai ajánlásokban egyértelműen 1. osztályú A-szintü ajánlás szívinfarktust követően a korai kardiológiai rehabilitáció, amely szignifikánsan csökkenti a halálozást (11). Hazai számítások készültek annak bizonyítására, hogyha kihasználjuk a kardiológiai rehabilitáció lehetőségeit, a munkaképes korosztály körében milliárdokban mérhető a nemzetgazdasági haszon (12). Legalább annyira fontos, hogy a betegek visszakapják egyéni önbecsülésüket, a társadalom aktív, megbecsült tagjai maradhatnak, akik nem szorulnak járadékokra. A betegség természetéről kapott információk segítik a betegek terápiahűségét, csökken az ismételt akut kórházi ellátásuk gyakorisága, a 30 napos és az egyéves halálozás. A multiprofesszionális intézeti - a későbbiekben ambuláns - rehabilitációs program egységes szakmai irányelvek alapján minden arra alkalmas beteg számára indokolt. Javul a beteg életminősége, ezzel összefüggésben csökkennek az egészségügyi kiadások.

\section{Irodalom}

1. Józan $P$. Fordulat a halandóságban és az életkilátásokban, epidemiológiai korszakváltás Magyarországon. OH 2003; 144: 451-460.

2. Jánosi A. A szívinfarktus miatt kezelt betegek ellátásának és prognózisának fontosabb adatai - Nemzeti Szívinfarktus Regiszter 2015. Card Hung 2016; 46: 70-75. real.mtak.hu/35880/1/650.2016.30339.pdf

3. Jánosi A, Ofner P, Merkely B, et al. Szívinfarktus miatt kezelt betegek korai és késői prognózisa Magyar Infarctus Regiszter Vizsgála. OH 154(33): 1297-1302.

4. Berényi I, Czuriga I, Simon A, Simon É, Szász K, Veress G. Ischaemiás szívbetegek rehabilitációja. Kardiológiai Szakmai Kollégium. Kardiológiai Útmutató. Klinikai Irányelvek Kézikönyve. Medition Kiadó; 2010. Március. pp. 99-108.

5. Piotr Ponikowski, Adriaan A. Voorsatal. 2016 ESC Guidelines for the diagnosis and treatment of acute and chronic heart failure. EurHeart J 20 May 2016. https://doi.org/10.1093/eurheartj/ehw128 2016 6. American Association of Cardiovascular and Pulmonary Rehabilitation (AACVPR). Guidelines for Cardiac Rehabilitation and Secondary Prevention Programs $5^{\text {th }}$ Edition 2013. Champain, IL: Human Kinetics ISBN-13: 9781450459648

7. Piepoli MF, Corra U, Adamopoulos S, et al. Secondary prevention in the clinical management of patients with cardiovascular diseases. Core components, standards and outcome measures for referral and delivery. Eur J PrevCardiol 2012; 21: 664-81. https://doi. org/10.1177/2047487312449597

8. Piepoli MF, Hoes AW, Agewall S, et al. 2016 European Guidelines on cardiovascular disease prevention in clinical practice. Eur Heart J Advance Access published 2016 May 23. https://doi.org/10.1093/ eurheartj/ehw106

9. Pavy B, barbet R, Carré F, et al. Therapeutic education in coronary heart disease. Arch of Cardiovasc Diseases 2013 Dec 12; 106: 680-689. http://dx.doi.org/10.1016/j.acvd.2013.10.002

10. Oldridge N, Furlong W, Feen D, et al. Economic evaluation of cardiac rehabilitation soon after acute myocardial infarction. Am J Card 1993; 72: 154-161. https://www.ncbi.nlm.nih.gov/pubmed/8328376

11. Kureshi F, Kennedy KF, Jones PG, et al: Association Between Cardiac Rehabilitation Participation and Health Status Outcomes After Acute Myocardial Infarction. JAMA Cardiol 2016; 1(9): 980988. https://doi.org/10.1001/jamacardio.2016.3458

12. Simon É. A kardiológiai rehabilitáció nemzetgazdasági jelentősége. Megoldási javaslatok a költséghatékonyság javítására Doktori (PhD) értekezés. 2012. p. 105-113. doktori.nyme.hu/352/2/magyar. pdf 